International Journal of Engineering \& Technology, $7(3.32)(2018) 15-18$
International Journal of Engineering \& Technology
SPC

\title{
Corrosion Investigation of Commercially Available Linepipe Steel in $\mathrm{CO}_{2}$ Environment
}

\author{
Muhammad Haris ${ }^{1}$, Saeid Kakooei ${ }^{1 *}$, Mokhtar Che Ismail $^{1}$ \\ ${ }^{I}$ Centre for Corrosion Research, Department of Mechanical Engineering, Universiti Teknologi PETRONAS, 32610 Seri Iskandar, Perak \\ Darul Ridzuan, Malaysia. \\ *Corresponding author E-mail: saeid.kakooei@utp.edu.my
}

\begin{abstract}
$\mathrm{CO}_{2}$ corrosion has been the most prevalent form of corrosion and is considered as a complex problem in oil and gas production indu stries The $\mathrm{CO}_{2}$ in presence of water causes sweet corrosion that is responsible for failure of pipeline during transportation of Oil and Gas. This work studies the corrosion behaviour of carbon steel specimens in $\mathrm{CO}_{2}$ environment at different temperatures but at constant pressure. The effect of $\mathrm{CO}_{2}$ on Carbon Steel specimens (X65, A106) were studied in simulated solution of 3 wt.\% NaCl. The specimens were immersed into the $\mathrm{CO}_{2}$ containing solution for 48 hours and corrosion behaviour was investigated by using electrochemical test like Linear Polarization Resistance and Tafel plot. The results indicate that the temperature has an important effect of corrosion rate of carbon Steel in $\mathrm{CO}_{2}$ environment. Corrosion rate of $1.5-2 \mathrm{~mm} / \mathrm{yr}$ was reported for both steels at lower temperature while at higher temperature the difference can be observed due to difference in protective nature of steels. Similar Corrosion rate around $1.5-2 \mathrm{~mm} / \mathrm{yr}$ was observed at $25^{\circ} \mathrm{C}$ for both $\mathrm{A} 106$ and $\mathrm{X} 65$ while at $50^{\circ} \mathrm{C}$ and $75^{\circ} \mathrm{C}$ the corrosion rate varies significantly $1.5-3 \mathrm{~mm} / \mathrm{yr}$ and $3.5-6 \mathrm{~mm} / \mathrm{yr}$.
\end{abstract}

Keywords: Carbon Steel; $\mathrm{CO}_{2}$ Corrosion; Linear Polarization Resistance.

\section{Introduction}

Oil and gas well mostly carries some water and different amount of gases and acid of which most notably are either carbon dioxide or in some cases is hydrogen sulphide. The presence of these affect the service life and integrity of carbon steel [1, 2]. Among these, carbon dioxide corrosion commonly known as sweet corrosion has been an area of interest for many researchers who had widely studied this phenomenon since the 70's regarding the corrosion resistance of the carbon steel. The degradation of steel due to carbon dioxide corrosion is an important problem with major implications for oil and gas industries [3]. The production of oil and gas and consumption of their products had grown significantly over the past years, this in turn had amplified the use of carbon steel pipelines for the transportation of these product over larger distance. To quench the thirst of growing demand of energy, the necessity of finding new methods for discovering oil \& gas has pushed operational activities to more rough environment that offer harsher operating conditions. All these factors imposed great challenges to the economics and subsequent operations wherein proper material selection and equipment integrity are becoming vital. Similar grades of carbon steel obtained through different processing techniques had been observed with varying corrosive behaviour when encounter with $\mathrm{CO}_{2}$ corrosion. Due to its low cost and economic feasibility, carbon steel is widely used as a construction material in transportation of oil and gas over larger distance[4-7]. However, this being said the susceptibility of carbon steel to $\mathrm{CO}_{2}$ corrosion cannot be denied and a number of authors have studied various aspects of carbon steel in parallel to the development of carbon steel application[6-10].
Thus far a number of studies indicated the effect of alloying elements including chromium that has the most profound effect on the corrosion resistance of carbon steel in $\mathrm{CO}_{2}$ environment along with this some other micro addition of alloying elements like Mn, $\mathrm{Si}, \mathrm{V}$ as well as processing route of which microstructure of steel is dependent upon[1, 2, 4, 7, 11]. However, it still need further investigation to analyse the optimum composition of these alloying elements. Their study search for how these factors influence corrosion by using Electrochemical corrosion techniques under $\mathrm{CO}_{2}$ environment and using this opportunity to better understand corrosion resistance of these alloy. This work seeks to understand better how the carbon steels behaves in simulated $\mathrm{CO}_{2}$ environment and their corrosion resistance were determined by the electrochemical test including Linear polarization resistance and Tafel polarization at different temperatures.

\section{Materials and Methods}

\subsection{Materials}

Steels samples of X65 and A106 were used for the investigation of corrosion rate at $\mathrm{CO}_{2}$ pressure of 1 bar at different temperatures. The composition of the carbon steel specimens is shown in following Table-1: 
Table 1: Chemical composition carbon steel specimens

\begin{tabular}{|c|c|c|c|c|c|c|c|c|c|c|}
\hline Steel(s) & $\mathrm{C}$ & $\mathrm{Cr}$ & $\mathrm{Mn}$ & $\mathrm{Si}$ & $\mathrm{Nb}$ & V & $\mathrm{Ti}$ & $\mathrm{P}$ & S & $\mathrm{Ni}$ \\
\hline & \multicolumn{10}{|c|}{ (Wt.\%) } \\
\hline X65 & o & ' & $\dot{\circlearrowright}$ & $\begin{array}{l}\stackrel{0}{+} \\
\text { ur }\end{array}$ & $\begin{array}{l}\text { P } \\
\dot{0}\end{array}$ & $\stackrel{\circ}{\circ}$ & $\begin{array}{l}\circ \\
\stackrel{\circ}{\circ}\end{array}$ & $\begin{array}{l}0 \\
0 \\
\text { N }\end{array}$ & $\begin{array}{l}0 \\
\stackrel{0}{0} \\
\text { ur }\end{array}$ & ' \\
\hline A106 & i & $\stackrel{\circ}{=}$ & $\underset{\substack{\infty \\
\sim \\
\sim}}{0}$ & 品 & ' & $\begin{array}{l}\stackrel{0}{\circ} \\
\stackrel{8}{0}\end{array}$ & $\begin{array}{l}0 \\
\dot{0} \\
0\end{array}$ & $\begin{array}{l}\stackrel{0}{0} \\
\stackrel{0}{N}\end{array}$ & 잉 & $\stackrel{0}{0}$ \\
\hline
\end{tabular}

\subsection{Sample Preparation}

All samples were cut in $10 \mathrm{~mm} \times 10 \mathrm{~mm} \times 3 \mathrm{~mm}$ and connected with Copper wire via soldering then embedded with phenolic molding powder with a working surface of $1 \mathrm{~cm}^{2}$ left. All samples were subsequently grind with 60 to 600 grit size emery papers, and then washed with distilled water, rinsed in acetone to remove any residue on the surface of the samples.

\subsection{Solution Preparation}

The electrochemical tests were carried out on METROHM AUTOLAB Potentiostat/galvanostat. Test solution for each experiment i.e. brine was prepared by dissolving sodium chloride (noniodized $\mathrm{NaCl}$ ) with DI water to make 3 wt.\% solution. $\mathrm{CO}_{2}$ gas was purged in the electrolyte for at least 1 hours prior to the test for removal of oxygen. All electrochemical test reading was done by using three electrode glass cell as shown in Fig. 1 with an $\mathrm{Ag} / \mathrm{AgCl}$ as the reference electrode, the steel samples as the working electrode, and stainless steel as the counter electrode. The LPR measurement were taken at $\pm 10 \mathrm{mV}$ around the open circuit potential (OCP) by using Potentiodynamic scan rate at $0.16 \mathrm{mV} / \mathrm{s}$ and reading was obtained after every hour for 48 hours. For Tafel polarization anodic and cathodic sweep was conducted towards the end of 48 hours of test at $\pm 250 \mathrm{mV}$ around the corrosion potential at a scan rate of $0.16 \mathrm{mV} / \mathrm{s}$. The $\mathrm{CO}_{2}$ was purged throughout the experiment. The $\mathrm{pH}$ of the solution was $\sim 3.7$ at the start of the experiments. The test was done at three different temperatures i.e. $25^{\circ} \mathrm{C}, 50^{\circ} \mathrm{C}$ and $75^{\circ} \mathrm{C}$.

\subsection{Corrosion Testing}

The electrochemical tests were carried out on METROHM AUTOLAB Potentiostat/galvanostat. Test solution for each experiment i.e. brine was prepared by dissolving sodium chloride (noniodized $\mathrm{NaCl}$ ) with DI water to make 3 wt.\% solution. $\mathrm{CO}_{2}$ gas was purged in the electrolyte for at least 1 hours prior to the test for removal of oxygen. All electrochemical test reading was done by using three electrode glass cell as shown in Fig. 1 with an $\mathrm{Ag} / \mathrm{AgCl}$ as the reference electrode, the steel samples as the working electrode, and stainless steel as the counter electrode. The LPR measurement were taken at $\pm 10 \mathrm{mV}$ around the open circuit potential (OCP) by using Potentiodynamic scan rate at $0.16 \mathrm{mV} / \mathrm{s}$ and reading was obtained after every hour for 48 hours. For Tafel polarization anodic and cathodic sweep was conducted towards the end of 48 hours of test at $\pm 250 \mathrm{mV}$ around the corrosion potential at a scan rate of $0.16 \mathrm{mV} / \mathrm{s}$. The $\mathrm{CO}_{2}$ was purged throughout the experiment. The $\mathrm{pH}$ of the solution was $\sim 3.7$ at the start of the experiments. The test was done at three different temperatures i.e. $25^{\circ} \mathrm{C}, 50^{\circ} \mathrm{C}$ and $75^{\circ} \mathrm{C}$.

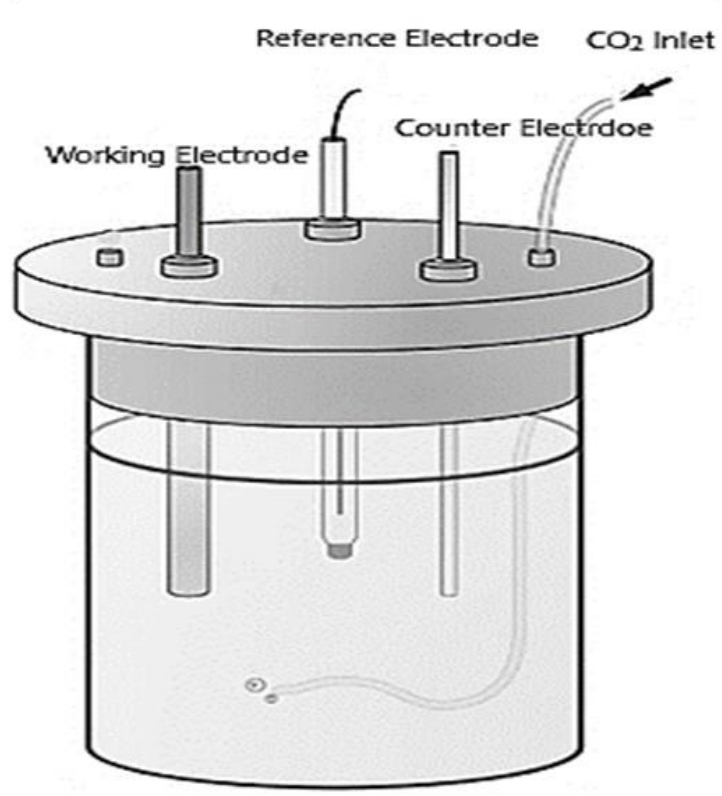

Fig 1: Schematic of 3-cell electrode glass cell

\section{Result and Discussion}

The linear polarization resistance and Tafel polarization plots are shown in Fig. 2, Fig. 3 and Fig. 4 at $25^{\circ} \mathrm{C}, 50^{\circ} \mathrm{C}$ and $75^{\circ} \mathrm{C}$, respectively. The sweep range for Tafel plots were -250 to $+250 \mathrm{mV}$ vs. open circuit potential $\left(E_{o c}\right)$ and the sweep rate of $0.167 \mathrm{mV} / \mathrm{s}$. The Potentiodynamic curve indicate that the Ecorr of A106 was relatively more positive than of X65 steel as shown in Table 2.

Table 2: $\mathrm{E}_{\text {corr }}$ of $\mathrm{A} 106$ \& X65 Steel

\begin{tabular}{|c|c|c|c|}
\hline Carbon Steel Specimen & $25^{\circ} \mathrm{C}$ & $50^{\circ} \mathrm{C}$ & $75^{\circ} \mathrm{C}$ \\
\hline Ecorr of X65 & $-580 \mathrm{mV}$ & $-645 \mathrm{mV}$ & $-670 \mathrm{mV}$ \\
\hline Ecorr of A106 & $-640 \mathrm{mV}$ & $-655 \mathrm{mV}$ & $-680 \mathrm{mV}$ \\
\hline
\end{tabular}

The cathodic curve of X65 and A106 steels show little variations as shown in Fig. 2 and Fig. 3 while the anodic current density depends on the steel grades and its composition.

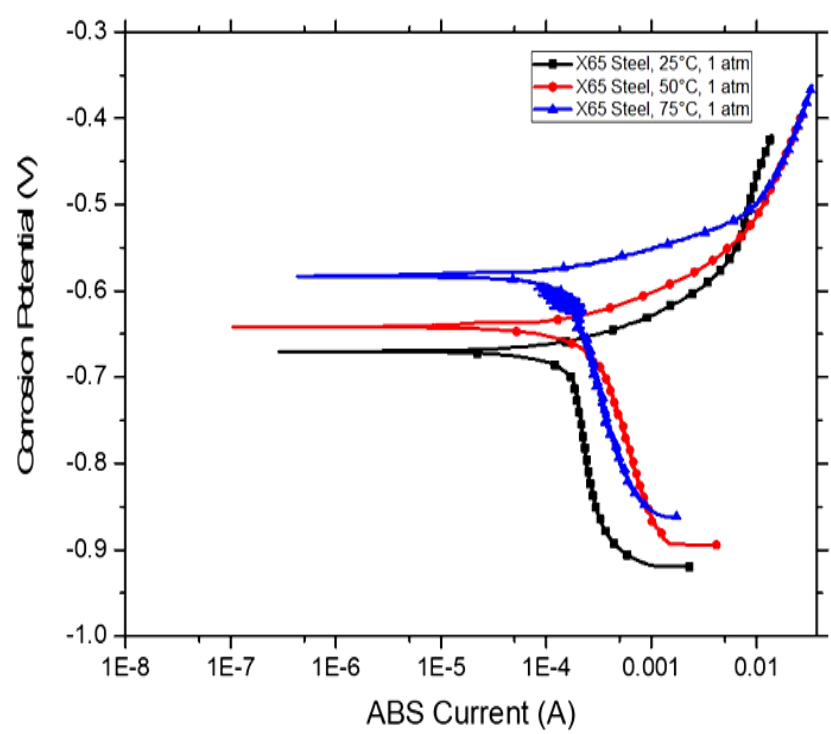

Fig. 2: Polarization plot of $\mathrm{X} 65$ steel at $25^{\circ} \mathrm{C}, 50^{\circ} \mathrm{C}$ and $75^{\circ} \mathrm{C}$ 


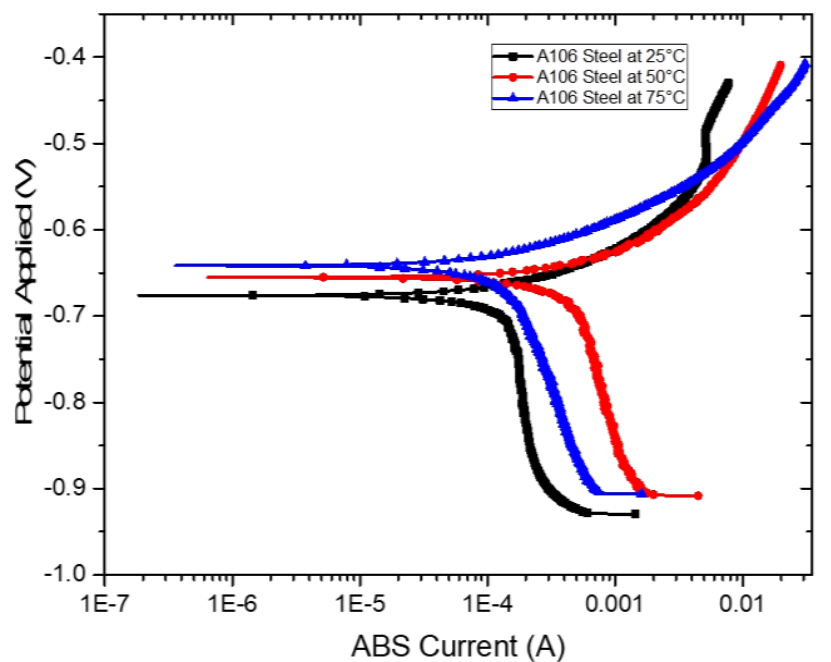

Fig 3: Tafel polarization plot of $\mathrm{A} 106$ steel at $25^{\circ} \mathrm{C}, 50^{\circ} \mathrm{C}$ and $75^{\circ} \mathrm{C}$

These results are consistent with data obtained from LPR test. Linear polarization resistance test was conducted by polarizing the both steel specimen to $\pm 10 \mathrm{mV}$ at a sweep rate of $0.167 \mathrm{mV} / \mathrm{s}$. The corrosion rate was calculated by using the following Equation 1 :

$$
\mathrm{CR}=\frac{302.11 \mathrm{~mm}}{\text { Rp.A yr }}
$$

Where;

$\mathrm{R}_{\mathrm{p}}=$ polarization resistance of in $\Omega . \mathrm{cm}^{2}$.

$\mathrm{A}=$ area of the sample in $\mathrm{cm}^{2}$.

The corrosion rate of $\mathrm{X} 65$ and $\mathrm{A} 106$ steel under $\mathrm{CO}_{2}$ environment have been illustrated in fig. 4 and 5. The samples were tested for 48 hours, an acceleration in corrosion rate can be seen as the temperature increases, this phenomenon can be linked to the less formation of ferrous carbonate layer as well as the rate of corrosion increase with the immersion time for carbon steel[12]. The lower corrosion rate reported for A106 steel at higher temperature can be credited to the presence of protective layer on the surface of steels predominantly in A106 as shown in fig. 6. There was difference of the corrosion rate of both steels at the end of the experiment as shown in fig. 8. SEM results in fig. 6 shows localized growth of ferrous carbonate crystals in localized region of both the samples at $75^{\circ} \mathrm{C}$ but A106 steel sample seems to have grown more densely by complete formation of crystal as compared to X65 steel [1]. The growth of ferrous carbonate crystal had a thin flake morphology that confirm that it growth rate was anisotropic. A variable corrosion rate can be observed for A106 and X65 steel due to the localized ferrous carbonate film that formed at higher temperatures [13-14]. SEM result in Fig. 7 at $50^{\circ} \mathrm{C}$ shows porous sponge films that may be $\mathrm{Fe}_{3} \mathrm{C} / \mathrm{FeCO}_{3}$ [1] which is non adherent layer on the surface that is weaker as compared to $\mathrm{FeCO}_{3}$ layer.

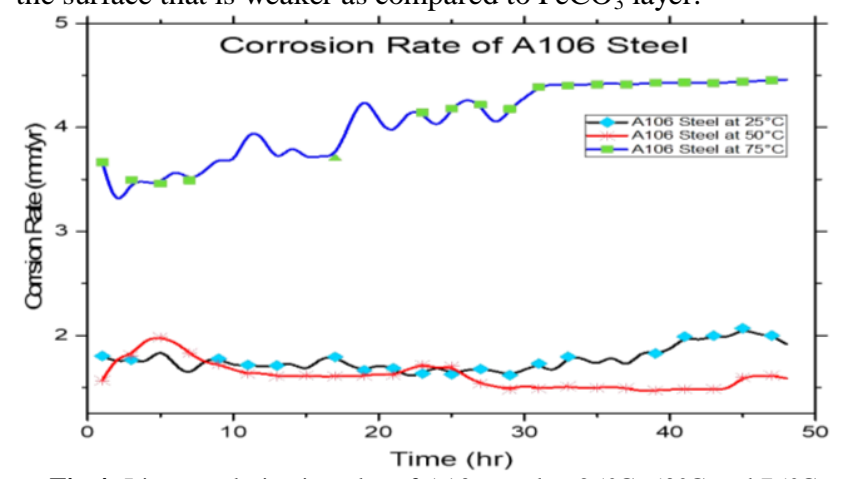

Fig 4: Linear polarization plot of A106 steel at $25^{\circ} \mathrm{C}, 50^{\circ} \mathrm{C}$ and $75^{\circ} \mathrm{C}$

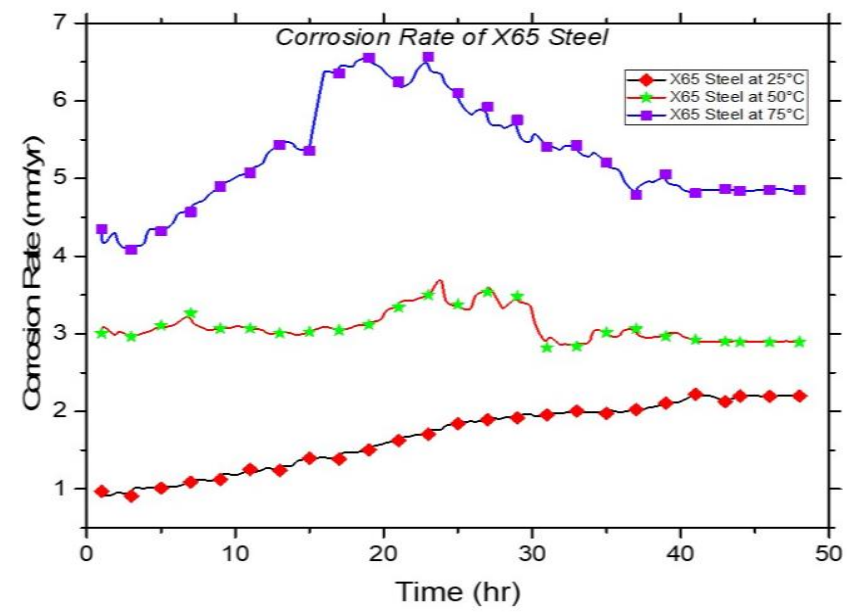

Fig 5: Linear polarization plot of $\mathrm{X} 65$ steel at $25^{\circ} \mathrm{C}, 50^{\circ} \mathrm{C}$ and $75^{\circ} \mathrm{C}$

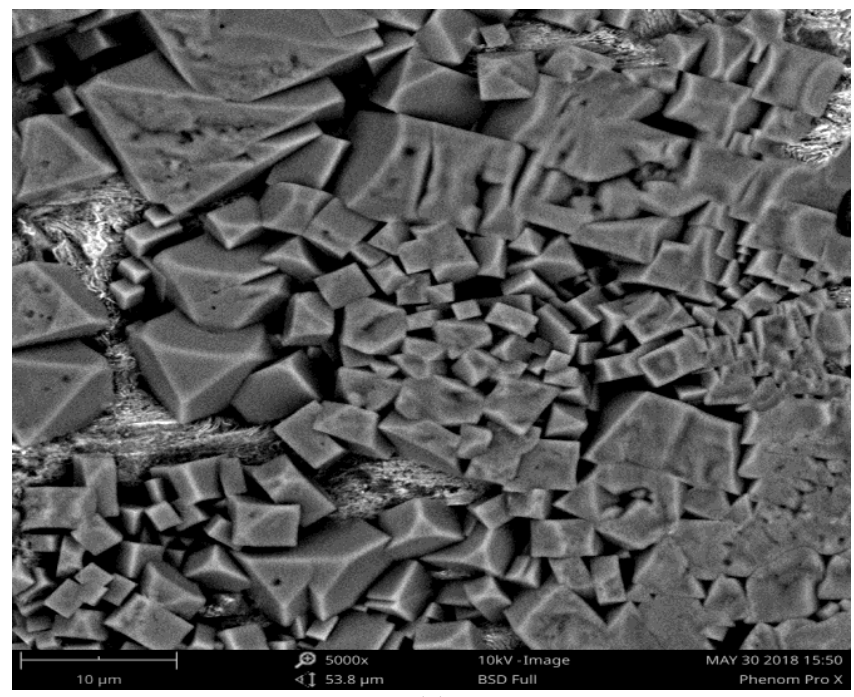

(a)

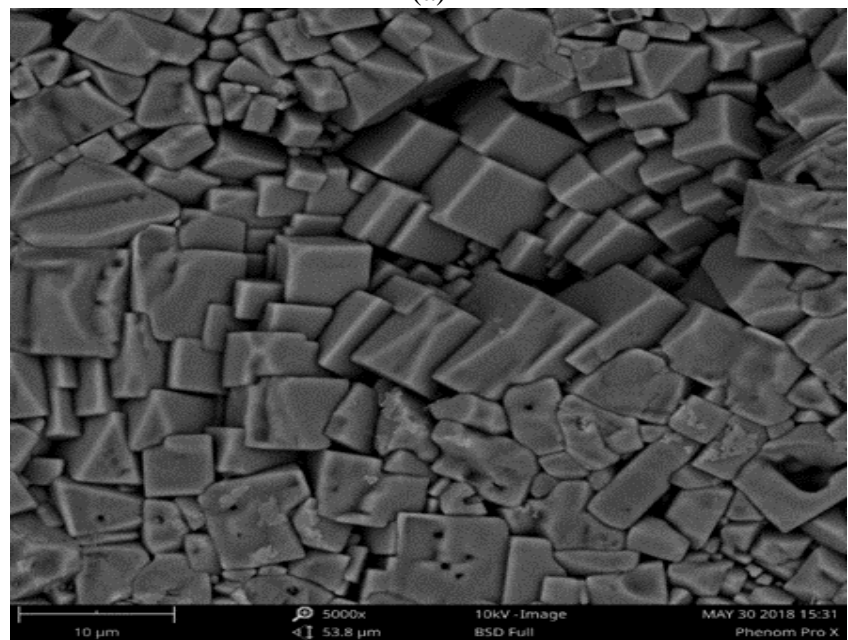

(b)

Fig 6: SEM image of X65 steel (a) and A106 steel (b) after 48 hours of Immersion at $\mathrm{T}=75^{\circ} \mathrm{C}, \mathrm{P}=1 \mathrm{~atm}$., $\mathrm{pH}=3.8$ and 3 wt. $\% \mathrm{NaCl}$. 


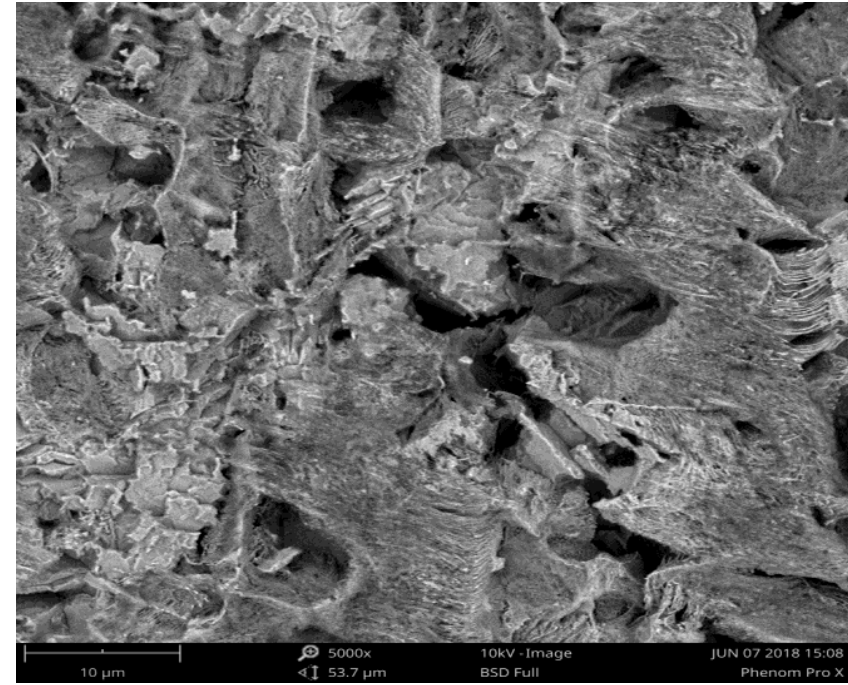

(a)

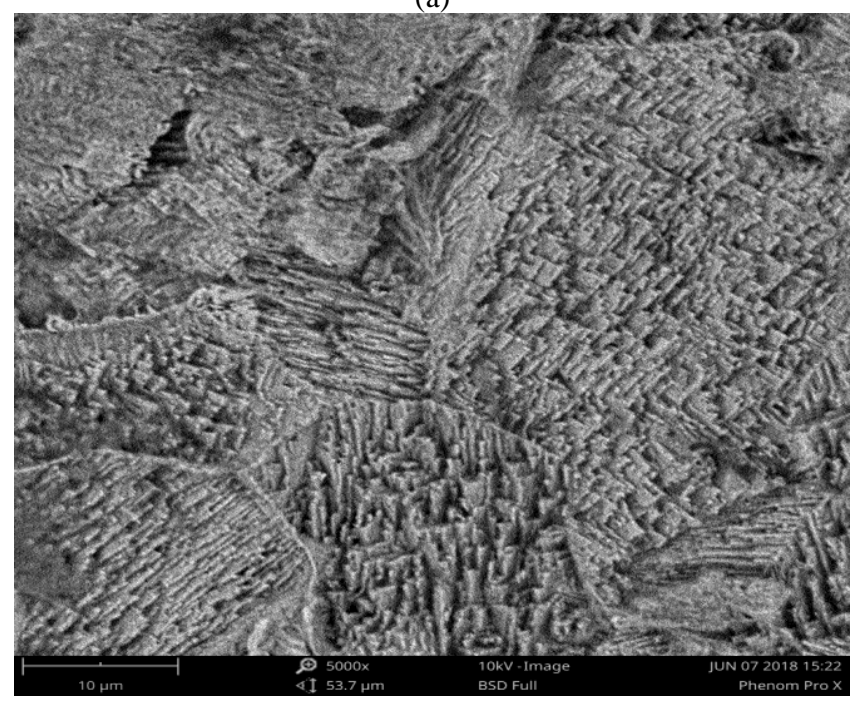

(b)

Fig 7: SEM image of X65 steel (a) and A106 steel (b) after 48 hours of Immersion at $\mathrm{T}=50^{\circ} \mathrm{C}, \mathrm{P}=1 \mathrm{~atm}$., $\mathrm{pH}=3.8$ and $3 \mathrm{wt}$. $\% \mathrm{NaCl}$.

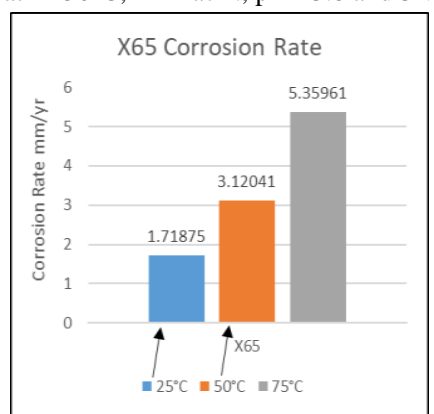

Fig. 8: Average Corrosion Rate of X65 Steel and A106 Steel at $25^{\circ} \mathrm{C}$ $50^{\circ} \mathrm{C}$ and $75^{\circ}$

\section{Conclusion}

It can be concluded that both type of carbon steels used in this study showed similar corrosion rates $(1.7 \mathrm{~mm} / \mathrm{yr}$. $)$ at $25^{\circ} \mathrm{C}$ in $\mathrm{CO}_{2}$ environment, but at higher temperature i.e. $50^{\circ}$ and $75^{\circ} \mathrm{C}$ the corrosion rate varies significantly, and it is attributed to the different nature of protective layer formed on both steels. A106 steels showed a superior corrosion resistance as compared to X65 steel under the same mentioned condition due to the presence of alloying elements and its ability to form ferrous carbonate layer at $75^{\circ} \mathrm{C}$ on its surface as shown from SEM results.

\section{Acknowledgement}

The author hereby acknowledges the financial support from Universiti Teknologi PETRONAS (UTP), Malaysia under Graduate Assistance Scheme.

\section{References}

[1] M. Kermani and A. Morshed, "Carbon dioxide corrosion in oil and gas production - a compendium," Corrosion, vol. 59, no. 8, pp. 659-683, 2003

[2] S. Guo, L. Xu, L. Zhang, W. Chang, and M. Lu, "Corrosion of alloy steels containing $2 \%$ chromium in $\mathrm{CO} 2$ environments," Corrosion Science, vol. 63, pp. 246-258, 2012

[3] N. Ochoa, C. Vega, N. Pébère, J. Lacaze, and J. L. Brito, "CO2 corrosion resistance of carbon steel in relation with microstructure changes," Materials Chemistry and Physics, vol. 156, pp. 198-205, 2015.

[4] D. V. Edmonds and R. C. Cochrane, "The effect of alloying on the resistance of carbon steel for oilfield applications to $\mathrm{CO} 2$ corrosion," Materials Research, vol. 8, no. 4, pp. 377-385, 2005.

[5] O. C. Moghissi, L. Norris, P. J. Dusek, and B. Cookingham, "Internal corrosion direct assessment of gas transmission pipelines," in CORROSION 2002.

[6] J. Li et al., "Study on the corrosion behaviours of API X65 steel in wet gas environment containing CO2," Corrosion Engineering, Science and Technology, pp. 1-7, 2017.

[7] Q. Wu, Z. Zhang, X. Dong, and J. Yang, "Corrosion behavior of low-alloy steel containing $1 \%$ chromium in $\mathrm{CO} 2$ environments," Corrosion Science, vol. 75, pp. 400-408, 2013.

[8] A. Hossain, F. Gulshan, M. Ali, and A. Kurny, " Effect of $0.5 \mathrm{Wt} \%$ $\mathrm{Cr}$ Addition on the Mechanical Properties and Microstructure of Heat Treated Plain Carbon Low Alloy Steel," presented at the Advances in Civil Engineering, Chittagong, Bangladesh, 2016.

[9] M. Alizadeh and S. Bordbar, "The influence of microstructure on the protective properties of the corrosion product layer generated on the welded API X70 steel in chloride solution," Corrosion Science, vol. 70, pp. 170-179, 2013.

[10] B. D. Craig and L. Smith, "Corrosion Resistant Alloys (CRAs) in the oil and gas industry," Nickel Institute Technical Series, no. 1, p. 0073, 2011.

[11] M. Ueda and H. Takabe, "Corrosion Resistance of Low Cr Bearing Steel in Sour and Sweet Environments," presented at the CORROSION 2002, Denver, Colorado, 2002.

[12] J. L. Mora-Mendoza and S. Turgoose, "Fe3C influence on the corrosion rate of mild steel in aqueous $\mathrm{CO} 2$ systems under turbulent flow conditions," Corrosion Science, vol. 44, no. 6, pp. 1223-1246, 2002/06/01/ 2002

[13] M. Hassan SK, A. M. Abdullah, M. Ko, N. Laycock, B. Ingham, and D. E. Williams, "Effects of Flow on Scales Formation in a $\mathrm{CO} 2$ Saturated Brine Environment," ECS Transactions, vol. 75, no. 30, pp. 17-31, January 5, 2017.

[14] S. Kakooei, M. C. Ismail, B. Raja, H. Mohebbi, S. S. Emamian, and M. Moayedfar, "Formation of Nano-Scale FeCO3 Protective Corrosion Product in Carbon Dioxide-Saturated 3\% Sodium Chloride Solution," in Key Engineering Materials, 2017, vol. 740, pp. 3-8: Trans Tech Publ. 